\title{
INFLUENCE OF LACTATION ORDER AND LIVE WEIGHT ON MILK YIELD AND FERTILITY TRAITS IN DOMESTIC BALKAN GOAT
}

\author{
N. Memiši ${ }^{1}$, M. Žujović ${ }^{2}$ Z. Tomić ${ }^{2}$, M. P. Petrović ${ }^{2}$ \\ ${ }^{1}$ AD Mlekara - Subotica, 24000 Subotica, Republic of Serbia \\ ${ }^{2}$ Institute for Animal Husbandry, 11080, Belgrade-Zemun, Republic of Serbia \\ Corresponding author: memisin@mlekara.rs \\ Original scientific paper
}

Abstract: The goal of investigation in the domestic Balkan goat was to establish the effect of body weight and lactation number on milk yield and fertility. Research was done in herds belonging to private farmers, during a one-year period, on a total of 578 goats. Investigated herds were monitored also by lactation number,i.e. kidding number (lactations 1,2 and 3 individually, lactation 4 and following lactations investigated together). Body weight and milk yield were measured, while fertility was determined as the number of live born kids per 100 goats.Goats were also sorted into groups by age and body weight, while the interval within groups and between groups was $5 \mathrm{~kg}$. Average total milk yield in the investigated population of the domestic Balkan goat was $177.5 \mathrm{~kg}$. A statististically significant difference $(\mathrm{P}<0,01)$ was established for milk yield depending on body weight and age, except for goats in lactation $1(\mathrm{P}<0,05)$. In lactation 3 and 4 , goats with body weights over $45 \mathrm{~kg}$, comprising $30.23 \%$ of the total number in these groups, had the highest milk yields (over $200 \mathrm{~kg}$ ). Pertaining to lactation number, i.e. kidding number, as well as body weight in both years of investigation, lowest fertility was found in lactations 1 and $2(112 \%)$, and in goats with lowest body weight $(25-30 \mathrm{~kg})$, while this considerably increased lactation 4 and later lactations (136\%), and body weights of over $40 \mathrm{~kg}(140 \%)$.

Key words: domestic Balkan goat, body weight, milkiness, fertility

\section{Introduction}

Numerous factors influence production potentials of goats, and beside the influence of nutrition as one of the most important paragenetic factors, the animal's body weight and age are considered as important. In used literature, by domestic and foreign authors, data on body weight of adult goats vary significantly. From the aspect of their successful reproduction and production, it is very important, while its expression is under a pronounced and decisive influence of breed, age, 
nutrition, care, etc. (Žujović et al., 2006; Memiši and Bauman, 2007; Memiši et al., 2008a, 2008b).

Milk yield is conditioned by numerous genes which directly or indirectly influence its expression. Milk yield is closely linked to external factors such as: nutrition before and after kidding, number of kids, climate and soil conditions, care, housing, etc. (Žujović et al., 2004; Memiši et al., 2008a,b,c). In their research certain authors have established positive correlations between body weight of goats and their milk yield and fertility (Zunev, 1995, Margetinova et al., 2003). However, certain research states that milk yield and fertility are under a decisive influence only of the age of animals, provided that other factors remain unchanged (Constantinou, 1985). When dealing with fertility of the domestic Balkan goat, it can be said that it is rather low, and that there is no significant volume of work to research and improve it, and that it has remained virtually unchanged to date. On the average, fertility is approximately $120 \%$, meaning that one goat will have 1.2 kids (Memiši, 2000).

In view of scarce literature data relevant to the effect of age and body weight on traits of production and reproduction in goats, and having in mind that in recent years goat breeding is really expanding in Serbia (Memiši and Bauman, 2002; Žujović et al., 2005), the goal of this investigation was to establish the effect of body weight and lactation number in the domestic Balkan goat, on milk yield and fertility. An additional reason is that, up to now, the Balkan goat has participated, in a high percentage (about 35\%), in the breeds composing the total goat population in our country (Memiši et al., 1998; Žujović et al., 2006;).

\section{Materials and Methods}

Research was done in herds belonging to private farmers, during a one-year period, on a total of 578 goats. Investigated herds were monitored also by milk production and fertility of goats depending on body weight of goats-dams and lactation number, i.e. kidding number (lactations 1,2 and 3 individually, lactation 4 and following lactations investigated together).

Milk productuion of controled goats $(\mathrm{n}=578)$, was measured from no later than day 10 after kidding, and until the end of the lactation (switch to once daily milking). All controled goats were in A type control. Milk production was controled twice daily at equal intervals (6 AM and around 8 PM), at 28-32 day intervals Fertility was determined as the number of live born kids per 100 goats.Goats were also sorted into groups by age and body weight, while the interval within groups and between groups was $5 \mathrm{~kg}$.

Statistical data processing for milk production and fertility of goats depending on body weight of goats-dams and lactation number, i.e. kidding number, was done using a PC and the least square mean method (Harvey, 1990). The final data processing model was:

$$
\mathrm{Y}_{\mathrm{ijkl}}=\mu+\mathrm{S}_{\mathrm{i}}+\mathrm{L}_{\mathrm{k}}+\mathrm{T}_{\mathrm{j}}+\mathrm{eijkl}
$$


where:

$\mathrm{Y}_{\mathrm{ijkl}}$ - phenotypic value of the particular traits included in the analysis, $\mu$ - overall average value,

$\mathrm{L}_{\mathrm{k}}$ - fixed effect of lactation order of dams $(\mathrm{j}=1, . .4)$,

$\mathrm{T}_{\mathrm{j}}$ - fixed effect body weight of goats $(\mathrm{j}=1 \ldots 5)$, and

eijkl - other undetermined effects (random error).

The statistical significance of the effect considered was evaluated by means of analysis of variance at the level P-0.05 and P-0.01. Variations between each mean value were also tested using the t-test.

\section{Results and Discussion}

Table 1 contains data on milk yield and fertility of the domestic Balkan goat depending on lactation number, i.e. age and body weight of goats-dams.

As data in Table 1 shows, most goats in lactations 2, 3 and 4, were in the groups with body weights between 31 and $35 \mathrm{~kg}(27.33 \%)$ and between 36 and 40 $\mathrm{kg}(28.89 \%)$, while the majority of goats in the investigated population with body weights over $45 \mathrm{~kg}$ were in lactation 3, 4 and later lactations, which is understandable since the domestic Balkan goat matures later, ending its growth approximately at 4 years of age.

In addition, it is evident that in lactation 1, but also in subsequent lactations, increase in body weight leads to increase of milk yield and better fertility. Average total milk yield in the investigated population of the domestic Balkan goat was $177.5 \mathrm{~kg}$. A statistically significant difference $(\mathrm{P}<0,01)$ was established for milk yield depending on body weight and age, except for goats in lactation $1(\mathrm{P}<0,05)$. Lowest milk yield was found in 1 lactation order $(146.0 \mathrm{~kg})$, while this considerably increased lactation 4 and later lactations. In lactation 3 and 4 , goats with body weights over $45 \mathrm{~kg}$, comprising $30.23 \%$ of the total number in these groups, had the highest milk yields (over $200 \mathrm{~kg}$ ).

Pertaining to lactation number, i.e. kidding number, as well as body weight in this investigation, lowest fertility was found in lactations 1 and $2(112 \%)$, and in goats with lowest body weight $(25-30 \mathrm{~kg})$, while this considerably increased lactation 4 and later lactations (136\%), and body weights of over $40 \mathrm{~kg}(140 \%)$. A statistically significant difference $(\mathrm{P}<0,01)$ was established for fertility depending on body weight and age, except for goats in lactation $2(\mathrm{P}<0,05)$.

Results for age of the domestic Balkan goat on milk yield which were found during this investigation, are similar with results reported by some other authors. Some higher values than ours for age and milk yield according to the lactation order, were established in research of Margetinova et al., (2003) in 139 Slovak white goats, with average daily milk yields from 1062 to $1499 \mathrm{ml}$, from lactation 1 to lactation 5 in that order, with a statistically significant difference at the $\mathrm{P}>0.01$ level. A similar trend of increase in yield and fertility depending on age 
and lactation order is cited by Zunev (1995) in the Bulgarian white goat, as well as by other authors for other types of domestic animals. (Wasilewski, 1999).

Table 1. Average values and variability milk yield ans fertility on domestic Balkan goats depending on the their live weight

\begin{tabular}{|c|c|c|c|c|c|c|}
\hline \multirow{2}{*}{ Live weight, $\mathrm{kg}$} & \multirow[b]{2}{*}{$\mathrm{n}$} & \multicolumn{3}{|c|}{ M il kin ess, kg } & \multicolumn{2}{|c|}{ Fertility, $\%$} \\
\hline & & LSM & $\pm \mathrm{SE}$ & $\mathrm{Cv}(\%)$ & $\mathbf{x}$ & $\pm \mathrm{Sx}$ \\
\hline \multicolumn{7}{|c|}{$1^{\text {st }}$ lactation } \\
\hline & & $*$ & & & & \\
\hline $25-30$ & 61 & 141.7 & 3.84 & 21.41 & 104.9 & 7.12 \\
\hline $31-35$ & 40 & 149.6 & 3.54 & 23.32 & 117.5 & 9.61 \\
\hline $36-40$ & 23 & 151.3 & 5.67 & 25.26 & 126.1 & 14.35 \\
\hline $41-45$ & - & - & - & - & - & - \\
\hline over 45 & - & - & - & - & - & - \\
\hline Average $1^{\text {st }}$ lactation & 124 & 146.0 & 3.16 & 18.33 & 112.09 & 4.74 \\
\hline \multicolumn{7}{|c|}{$2^{\text {nd }}$ lactation } \\
\hline & & $* *$ & & & & \\
\hline $25-30$ & 12 & 146.5 & 5.29 & 25.11 & 108.3 & 17.31 \\
\hline $31-35$ & 42 & 161.6 & 3.79 & 23.58 & 116.6 & 8.94 \\
\hline $36-40$ & 68 & 180.2 & 3.74 & 23.11 & 113.2 & 7.28 \\
\hline $41-45$ & 31 & 186.7 & 4.29 & 21.48 & 119.3 & 13.01 \\
\hline over 45 & - & - & - & - & - & - \\
\hline Average $2^{\text {nd }}$ lactation & 153 & 173.8 & 2.89 & 24.69 & 113.1 & 4.16 \\
\hline \multicolumn{7}{|c|}{$3^{\text {th }}$ lactation } \\
\hline & & $* *$ & & & & \\
\hline $25-30$ & - & - & - & - & - & - \\
\hline $31-35$ & 8 & 164.5 & 6.72 & 24.12 & 112.5 & 19.42 \\
\hline $36-40$ & 40 & 187.8 & 4.12 & 25.13 & 125.0 & 9.74 \\
\hline $41-45$ & 56 & 180.8 & 3.81 & 19.26 & 128.5 & 8.14 \\
\hline over 45 & 27 & 205.8 & 4.62 & 21.35 & 133.5 & 13.52 \\
\hline Average $3^{\text {th }}$ lactation & 131 & 187.1 & 2.99 & 24.46 & 126.7 & 5.01 \\
\hline \multicolumn{7}{|c|}{$4^{\text {th }}$ lactation } \\
\hline & & ** & & & & \\
\hline $25-30$ & - & - & - & - & - & - \\
\hline $31-35$ & 11 & 187.4 & 5.96 & 23.46 & 118.2 & 17.36 \\
\hline $36-40$ & 36 & 181.2 & 3.12 & 19.26 & 138.8 & 8.76 \\
\hline $41-45$ & 59 & 202.4 & 3.49 & 22.15 & 140.6 & 7.43 \\
\hline over 45 & 64 & 214.7 & 3.15 & 24.72 & 139.0 & 6.55 \\
\hline Average $4^{\text {th }}$ lactation & 170 & 202.2 & 2.96 & 22.25 & 136.4 & 3.96 \\
\hline $\begin{array}{c}\text { Average } 1^{\text {st }}-4^{\text {th }} \\
\text { lactations }\end{array}$ & 578 & 177.5 & 2.15 & 26.37 & 122.8 & 3.08 \\
\hline
\end{tabular}

Based on above data for traits of yield and fertility of the domestic Balkan goat, it can be concluded with certainty that lactation rank, i.e. goat age, as well as body weight play a significant role in milk yield and fertility, indicating that future 
selection programs should use animals with best combinations of these investigated traits, in order to improve overall productivity of the investigated goat breed.

\title{
Conclusion
}

Results established for the effect of body weight, as well as of lactation order of the domestic Balkan goat, on milk yield and fertility, permit the following conclusions:

1. Starting from the first lactation to the fourth, increase of body weight leads to increase in milk yield, and a statistically significant difference $(\mathrm{P}<0.01)$ has been established for milk yield depending on body weight and goat age, except for goats in lactation $1(\mathrm{P}<0.05)$.

2. Lowest fertility was found in lactations 1 and $2(112 \%)$, and in goats with lowest body weight (25-30 kg), while this considerably increased lactation 4 and later lactations (136\%), and body weights of over $40 \mathrm{~kg}(140 \%)$. A statistically significant difference $(\mathrm{P}<0,01)$ was established for fertility depending on body weight and age, except for goats in lactation $2(\mathrm{P}<0,05)$.

3. Based on the above data fir milk yield and fertility traits for the domestic Balkan goat breed, it can be said with certainty that the order of lactation, i.e. goat age, as well as their body weight have an important influence on milk yield and fertility of animals.

\section{Uticaj laktacije po redu i telesne mase na prinos mleka i osobine plodnosti domaće balkanske koze}

\author{
N. Memiši, M. Žujović, Z. Tomić, M. P. Petrović
}

\section{Rezime}

Cilj ovih ispitivanja je bio da se utvrdi uticaj telesne mase, kao i uzrasta tj. laktacije po redu u domaće balkanske koze na njenu proizvodnju mleka i plodnost. Istraživanja su izvedena u stadima balkanskih koza privatnih odgajivača, u toku jednogodišnjeg perioda kod ukupno 578 grla koza.

Kontrola mlečnosti je izvođena dvokratno u jednakim vremenskim intervalima pri čemu su sva grla bila u A kontroli. Plodnost je determinisana kao broj živorođene jaradi na 100 koza. Koze su, takođe, podeljene u grupe prema uzrastu i telesnoj masi, pri čemu je interval unutar i između grupa bio $5 \mathrm{~kg}$. Prosečna vrednost za ukupnu količnu mleka kod ispitivane populacije koza iznosi $177,56 \mathrm{~kg}$. Statistički značajna razlika $(\mathrm{P}<0,01)$ je utvrđena za prinos mleka u 
zavisnosti od telesne mase i uzrasta kod svih ispitivanih grupa, izuzev za koze u prvoj laktaciji $(\mathrm{P}<0,05)$. U 3 i 4 laktaciji po redu, koze sa telesnom masom preko $45 \mathrm{~kg}$, koje učestvuju sa $30.23 \%$ od ukupnog broja grla u ovoj grupi, imale su najveći prinos mleka (preko $200 \mathrm{~kg}$ ). U zavisnosti od laktacije po redu tj., jarenja po redu, kao i telesne mase $u$ obe godine istraživanja, najniža plodnost je ustanovljena u 1 i 2 laktaciji po redu (112\%) i to kod koza sa najnižom telesnom masom (od 25-30 kg), dok se ona idući ka četvrtoj i kasnijim laktacijama po redu (136\%) i telesnoj masi preko $40 \mathrm{~kg}(140 \%)$ znatno povećava. Statistički značajna razlika na nivou $\mathrm{P}<0,01$, kada je $\mathrm{u}$ pitanju plodnost koza u zavisnosti od uzrasta tj. laktacije po redu i telesne mase utvrđena je kod svih ispitivanih grupa, izuzev kod koza u drugoj laktaciji $(\mathrm{P}<0,05)$

\section{References}

CONSTANTINOU A., MAVROGENIS A.P. (1985): Genetic and phenotypic parameters for milk yield, litter size and body weight in the Damascus goat. Animal Production, 60.

HARVEY W.R. (1990): Mixed Model Least Squares and Maximum Lidelihood Computer Program. User's Guide for LSMLMW and MIXMDL

MEMIŠI N., BOŽOVIĆ V., BAUMAN F., LATINOVIĆ D. (1998): Fenotipska varijabilnost proizvodnih osobina domaće balkanske koze. Savremena poljoprivreda, 46, 5-6, 110-115.

MEMIŠI N., (2000): Kvantitativna analiza telesne razvijenosti i proizvodnih osobina domaće balkanske koze. Doktorska disertacija. Poljoprivredni fakultet, Beograd.

MEMIŠI N., BAUMAN F. (2002) Koza. Poljoprivredna biblioteka. Beograd. MEMIŠI, N., FRIDA BAUMAN (2007) Goat Nutrition. Admiralbook. Belgrade, $232 \mathrm{pp}$.

MEMIŠI N., ŽUJOVIĆ M., BOGDANOVIĆ V., TOMIĆ Z., PETROVIĆ M.P. (2008a): The influence of presence of cadmium and arsenic in feedmealon production and reproduction traits of goats. Biotehnology in Animal Husbandry, 24, 3-4, 39-48.

MEMIŠI N., ŽUJOVIĆ M., BOGDANOVIĆ V., PETROVIĆ M.P. (2008b): Correlation analysis of production traits of domestic balkan goat. Biotehnology in Animal Husbandry, 24, 3-4, 49-56.

MEMIŠI N., ŽUJOVIĆ M., BOGDANOVIĆ V., PETROVIĆ M.P. (2008c): The level concentrate in meal of goat on production milk in lactation period. Biotehnology in Animal Husbandry, 24, spec.issue, 481-490.

MARGETINOVA J., BRUČEK J., APOLENI D., MIHINA Š. (2003): Relationship between age, milk production and order of goats during automatic milking. Czech J. Anim. Sci., 48, 6, 257-264 
ZUNEV P.(1995): Influence of live weight and age on the basic productive indices of female goats belonging to the Bulgarian white milky breed. Biotehnologija $u$ stočarstvu 11, 3-6, 125-128.

ŽUJOVIĆ M., TOMIĆ Z., JOSIPOVIĆ S., NEŠIĆ Z., ČINKULOV M., PIHLER, I. (2004): Stanje i mogućnosti kozarske proizvodnje. Acta agriculturae Serbica. Proceeding of 10th National Symposium on Forage Crops., IX, 17, 33-41.

ŽUJOVIĆ M., TOMIĆ Z., PETROVIĆ M.P., JOSIPOVIĆ S., NEŠIĆ Z. (2005): Importance and perspective of goat production in Republic of Serbia. Journal of Montain Agriculture on the Balkans, 8, 2, 120-154.

ŽUJOVIĆ, M., TOMIĆ Z., PETROVIĆ M.P., MEKIĆ C., IVANOVIĆ S., NEŠIĆ Z. (2006): Development and perspective of goat production in Serbia. Biotechnology in Animal Husbandry, 22, spec. iss., 43-56.

WASILEWSKI A. (1999): Demonstration and verification of a milking order in dairy sheep and its extent and consistency. Appl. Anim. Behav. Sci., 64, 111-124.

Received 17 May 2010; accepted for publication 16 June 2010 